\title{
A Service Science for Collaborative Enterprises - Observations and Theses on Future Developments
}

\author{
Kyrill Meyer \\ Universität Leipzig, Business Information Systems, Johannisgasse 26, \\ 04103 Leipzig, Germany \\ meyer@informatik.uni-leipzig.de
}

\begin{abstract}
The evolution of the global economy can be characterized through ever shorter life cycles for products and services while, at the same time, development costs increase and the time to bring a new idea into the market reduces. Collaboration has introduced itself as a promising approach to address various challenges enterprises are faced with in such a context. The paper presents a number of observations and theses that point towards future developments. In doing so, the role of services and their development as a major element for successful long-term cooperation in value networks or as a basis for the collaborative enterprise is presented. Instead of providing a clear outline, we will present a number of theses that point towards future developments.
\end{abstract}

Keywords: Service Science, Service Economy, Collaboration in Services.

\section{Introduction}

The evolution of the global economy can be characterized through ever shorter life cycles for products and services while, at the same time, development costs increase and the time to bring a new idea into the market reduces [1]. In the struggle to be innovative and competitive in the market, new products and solutions are increasingly developed in collaborative settings within value networks or entire value chains that involve more than one company or institution [2]. Collaboration has introduced itself as a promising approach to address various challenges enterprises are faced with in a knowledge driven society [3]. Thus, expert knowledge can be transferred, resource limitations overcome and expertise included that is not covered by one company itself, which is of high interest especially for small and medium sized enterprises (SME) [4].

In this paper we present a number of observations that the careful bystander will be able to note looking at this development and the background in the market against which they occur. We argue on the role of services and their development as a major element for successful long-term cooperation in value networks or as a basis for the collaborative enterprises. Instead of providing a clear outline, we will present a number of theses that point towards future developments. 


\section{Observations}

Observation I: The service economy is a reality.

The importance of services in modern economies has been continuously rising during the past decades. Today, about two thirds of the GDP in the EU Member States and in other western economies can be directly accounted to services [5]. Given the statistic frameworks such as the NACE nomenclature of economic activities this information is derived from, one needs to consider that the real significance of services will potentially be even higher. For example, if an industrial company provides services such as maintenance or a remote service for a machine it produces, this will most likely not be captured as service activity. Services are everywhere in the market and in many cases they are the real differentiating factor between competitors. Current studies show that many enterprises recognize the importance of services for their business and expect growth to come especially from new or improved service offerings [6]. For quite a number of companies services have taken a system leadership, meaning that not a specific product or offering is core of the business approach, but customer-oriented service solutions drive the company efforts [7, 8]. Such enterprises have adopted a view that is scientifically called the "servicedominant-logic" [9-11]. However, even with the given economic importance of services, many companies still act product-centered and the role and significance of services is neglected.

\section{Observation II: Service markets and demands change}

The economy and also the service sector undergo changes with their development. Along with the growing economic importance of services during the years the competition has intensified and the markets can be characterized as highly dynamic. Main factors of this development include:

- Deregulation and internationalization

- Market saturation and excess capacities

- Merging and emerging markets with the entry of new competitors

- Multiplication of successful service concepts

In this environment, companies offering services cannot be successful just through being cost-effective or with their marketing image. Long-term success is based on offering innovative solutions. These need to be based on an understanding for the needs of the customers, integrated into a holistic high-quality offering and provided with efficiency and productivity. A company needs to continuously improve their service portfolio and provide such service offerings faster than the competition. It might be that the company offering such service solutions needs to re-adjust their own view of services and organizational as well as management changes need to be implemented. 
Observation III: Technological infusion is a major driver for new services

The service economy is closely linked with the management of knowledge and information. With the possibility to collect and share information through networks such as the internet, new business and collaboration models arise that are mostly offered as services. Also existing services profit from the support through information technology because they can be provided in new forms (e.g. a remote service instead of a maintenance on location), with better efficiency or based in better connection to customer information.

Trends in this respect are the notions of "cyber-physical systems" or the "internetof-things". They refer to hard- and software that is embedded in goods, machines, buildings, means of transportation, logistic chains or manufacturing equipment. Such hard- and software collects information and data through sensors or interactions with users, processes them and is able to distribute and interact through interfaces in communication networks. In areas such as health, environment, transportation, logistics and communication the information acquired through such systems will be needed to manage complexity, but can only harvested to any benefit if their development is embedded in collaboration and service structures.

\section{Observation IV: Service Research is not coherent and clearly focused}

Given the significance of services, the market demands and the possibilities that arise from technology one could assume that major efforts and activities exist in the area of service research. In fact, there are scientific efforts to analyze, create and manage the socio-technical systems that produce services on the background of the technological, managerial, theoretical and design aspects involved. In doing so, service research is a highly multidisciplinary field [12] that is not yet clearly defined. Most research work conducted is part of the respective field such as sociology, anthropology, ergonomics, system science, computer science, marketing and business administration. Currently, the working areas of service research are part of the scientific discussion [12-14] and the viewpoint taken may differ. For example, some researchers argue from the viewpoint of an optimal service for the customer, while others have the focus of their work on the systematic engineering of the service delivery. While those differing perspectives are not adjacent to each other, they make it harder to form a common understanding of a service science. Also, one has to take into account that the contributing fields itself have varying background in respect to their own history and development.

\section{Theses}

\section{Thesis I: Services will be High-Tech/Smart in the future}

Looking at the potential development of the broad service field, one has to ask the question where innovation in services can take place. Research in the field of service 
innovation has identified three main areas for service innovation [15]: the concept of the service system itself, the way interaction within the service system takes place or the way the service is delivered through the service system. Interestingly, they are connected through a fourth field, the technological options (see figure 1).

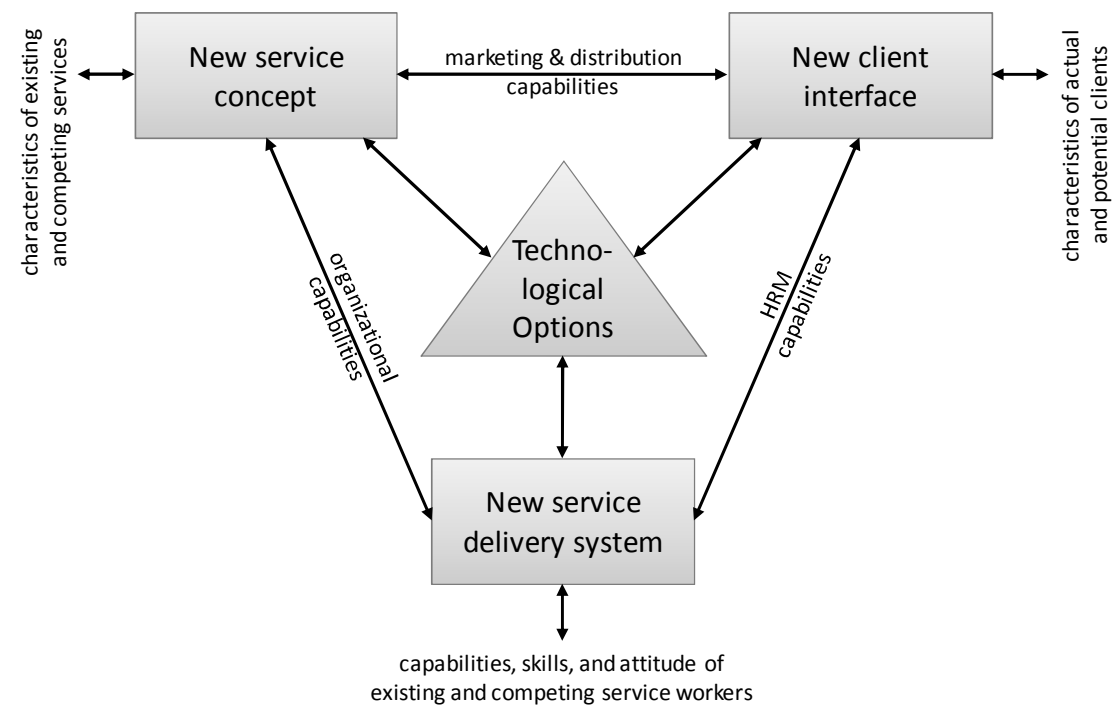

Fig. 1. The 4-D-Model of Service Innovation [15]

The model illustrates the high significance technology plays for future services. Many of the challenges modern societies are faced with can be addressed properly only if there is a proper technology support in the field (e.g. questions of health, mobility, energy security). Therefore, one can conclude that services need to be developed further into complex service systems that provide solutions that are hightech-based or can be called Smart Services because they incorporate technology that is helpful in the application field. On the other hand, if technology is not embedded properly within the service system, the potential it provides is lost (e.g. what good is a smart meter for water if there is no service connected with it).

\section{Thesis II: Managing system complexity will be core}

Service research has a long tradition in arguing about the key elements of a service and its characteristics [13]. Respectively, a general service definition will have to be generic. Currently, such approaches to define services focus on the elements service provider, service consumer and the service object/subject that is operated upon [16]. Those elements form a socio-technical service system, where the different elements form actors and resources and the service itself is a change of configuration of the service system. Those systems will be increasingly complex and the real challenge is not only to see in understanding the system, but also in managing its complexity. If 
for example, mobility services have to be switched away from fossil fuels, it is not only the question of where the batteries come from. Complex infrastructures have to be changed and entire value changes need to be restructured or built anew. So in the long run, if a company provides integrated solutions for questions or is able to contribute in a complex service system, this will be the key factor for success. For this, services need to be not only consumer oriented (whatever makes the customer happy), but need to be engineering. Here, the service engineering [17] is a valid approach that also focusses on identifying service components[18] and, by doing so, mange complexity through the division of the problem in manageable parts.

\section{Thesis III: Collaboration will be key}

The trigger for innovation in general can be divided into two streams: technology push and demand pull [19]. Technology push means that research gives rise to new technologies or applications that are thereafter applied to create new solutions. Demand pull means that the market signals a need for a solution to a particular problem which is then solved in the innovation process. The 1970s debate about the impact and importance of each of the triggers came to the conclusion that a separated view would be leading nowhere. In practice, innovation is a coupling and matching process where interaction and collaboration is essential. Successful innovation requires the interaction between (technology) "push" and (demand) "pull" actors. A strong potential lies, therefore, in the collaboration between typical push actors such public research institutions and typical pull actors such as small and medium sized enterprises[4]. It is also a very practical approach as it shows that in many cases companies that start technology driven do not become market leader in their respective technology but in the end are able to provided high-quality and dedicated services within a value chain or network. Overall to focus on collaboration as key for successful service development develops different aspects that for a single company will be hard to achieve by itself:

- cooperative R\&D activities and pooling of innovation stakeholders,

- reducing resources disadvantage,

- enabling a bottom-up information flow (demand driven) and combining it with topdown approaches (technology or result driven).

- successful establishment of value chain networks with dedicated and specialized actors that provide services to others

- network-structures with benefits to all participating actors and the creation of innovative milieus [19]

\section{Thesis IV: We need a Service Science}

Even though the service sector is the most important and fastest growing business sector of developed countries, we currently have no integrated service research or academic community. With the field developing, the lack of conceptual foundation [20] and the problems arising from the fact that there is no holistic research agenda 
for services become more and more apparent. For this reason, scientists call out for an academic discipline they call service science and put forward research agendas or plans to sharpen the understanding of services [8, 20, 21]. Service science is understood by many as a multidisciplinary field, focusing on the combination of fundamental science and engineering theories, models, and applications, aiming at enhancing and improving service innovation and giving insights on how to design, build and manage service systems [21-23].

To successful establish such a service science that provides applicable research results for the business world, service research needs a strong theoretical foundation but must also provide methods, procedures and tools that can be used to build and manage actuals service systems. Therefore, knowledge-focused basic research such as empirical studies and observations has to be combined and interlinked with application-focused approaches in cumulative and innovative ways [24].

A service science cannot be a merely academic effort. The phenomenological variety and the high significance of services for economic success and everyday life concerns many different knowledge and decision stakeholders from science, business and politics [24].

To harvest the potential such a service science brings to the service world we suggest building centers of service excellence at a number of research centers around the world, where theoretical work from the different contributing fields is combined with the possibility to design, engineer, test, measure and simulate services. Such service centers could be the core of an innovative milieu that stimulates cooperation and networking.

\section{Conclusions}

Research in the field of service, dealing with the engineering, design and management of increasingly complex socio-technical systems to provide services and solutions is a highly significant field, which has not yet reached is full potential. Being a collection of contributions from various fields at the moment, is remains to see whether an integrated service science will be able to form. Such a service science will have to focus on a systematic technology driven service systems engineering and management. It seems clear that collaboration structures and technology support play an important part in future service systems and for the companies providing those solutions. With its help, it will be easier to address the social, environmental and economic challenges of our societies. Due to their complexity it will be necessary to form collaboration structures in which different stakeholders, knowledge and solution providers can work together and provide services to each other that in the larger context define an overall service system.

\section{References}

1. Ball, D.A.: International business: the challenge of global competition. McGraw-Hill Irwin, Boston (2010)

2. Cases, M., Bodner, D.A., Mutnury, B.: Architecture of Service Organizations. In: Salvendy, G., Karwowski, W. (eds.) Introduction to Service Engineering, pp. 109-137. John Wiley and Sons, Hoboken (2010) 
3. Camarinha-Matos, L.M., Afsarmanesh, H.: Collaborative Networks - Value creation in a knowledge society. In: Wang, K., Kovacs, G.L., Wozny, M., Fang, M. (eds.) IFIP TC5 International Conference on Knowledge Enterprise: Intelligent Strategies in Product Design, Manufacturing, and Management; Proceedings of PROLAMAT 2006, Shanghai, China, June 15-17, vol. 207, pp. 26-40 (2006)

4. Thieme, M., Meyer, K.: Innovation through Collaboration: A Case-Study Based Strategy to Connect Research Institutions and Enterprises. In: Annual (SRII) Global Conference, SRII, pp. 622-629 (2011)

5. OECD: Evolution of Value Added by Activity. In: OECD Factbook 2010: Economic, Environmental and Social Statistics. OECD Publishing (2010)

6. Edvardsson, B., Meiren, T., Schäfer, A., Witell, L.: New Service Development in Europe Results from an empirical study. In: AMA SERVSIG International Service Research Conference, Porto, Portugal (2010)

7. Vandermerwe, S., Rada, J.: Servitization of business: Adding value by adding services. European Management Journal 6, 314-324 (1988)

8. Rust, R.T., Miu, C.: What academic research tells us about service. Commun. ACM 49, 49-54 (2006)

9. Vargo, S.L., Lusch, R.F.: Evolving to a New Dominant Logic for Marketing. Journal of Marketing 68, 1-17 (2004)

10. Vargo, S.L., Lusch, R.F.: From goods to service(s): Divergences and convergences of logics. Industrial Marketing Management 37, 254-259 (2008)

11. Vargo, S., Lusch, R.: Service-dominant logic: continuing the evolution. Journal of the Academy of Marketing Science 36, 1-10 (2008)

12. Fisk, R.P., Grove, S.J.: Broadening Service Marketing: Building a Multidisciplinary Field. In: Spath, D., Ganz, W. (eds.) Teh Future of Services, pp. 233-244. Carl-Hanser-Verlag, München (2008)

13. Edvardsson, B., Gustafsson, A., Roos, I.: Service portraits in service research: a critical review. International Journal of Service Industry Management 16, 107-121 (2005)

14. Edvardsson, B.: Development of Service Research in Europe against the background of Global economic Change: Experiences, Challenges and Trends. In: Streich, D., Wahl, D. (eds.) Moderne Dienstleistungen, pp. 23-26. Campus, Frankfurt/Main (2006)

15. Hertog, P.d.: Knowledge-intensive business services as co-producers of innovation. International Journal of Innovation Management 4, 491-528 (2000)

16. Araujo, L., Spring, M.: Services, products, and the institutional structure of production. Industrial Marketing Management 35, 797-805 (2006)

17. Bullinger, H.-J., Fähnrich, K.-P., Meiren, T.: Service Engineering - methodical development of new service products. International Journal of Production Economics 85, 275-287 (2003)

18. Böttcher, M., Klingner, S.: Providing a Method for Composing Modular B2B-Services. Journal of Business and Industrial Marketing 26, 320-331 (2011)

19. Marinova, D., Phillimore, J.: Models of Innovation. In: Shavinina, L.V. (ed.) The International Handbook on Innovation, pp. 44-53. Pergamon, Amsterdam (2007)

20. Chesbrough, H., Spohrer, J.: A research manifesto for services science. Commun. ACM 49, 35-40 (2006)

21. Ostrom, A.L., Bitner, M.J., Brown, S.W., Burkhard, K.A., Goul, M., Smith-Daniels, V., Demirkan, H., Rabinovich, E.: Moving Forward and Making a Difference: Research Priorities for the Science of Service. Journal of Service Research (2010) 
22. Paton, R.A., McLaughlin, S.: The Services Science and Innovation Series. European Management Journal 26, 75-76 (2008)

23. Paulson, L.D.: Services Science: A New Field for Today's Economy, vol. 39, pp. 18-21 (2006)

24. Ganz, W., Tombeil, A.-S.: Institutionalisation in the context of new forms of knowledge production. In: Spath, D., Ganz, W. (eds.) The Future of Services: Trends and Perspectives. Carl-Hanser-Verlag, München (2009) 